\title{
Performance of Hybrid Maize as Influenced by Fertigation Management Practices
}

\author{
M.K. Shruthi", T. Sheshadri and S.B. Yogananda \\ Department of Agronomy, University of Agriculture Sciences, GKVK, Bengaluru-65, \\ Karnataka, India \\ *Corresponding author
}

\section{Keywords}

Drip irrigation,

Fertigation interval,

Kernelyield, Harvest

index, Nutrient uptake

Article Info

Accepted:

12 February 2018

Available Online:

10 March 2018

\section{A B S T R A C T}

A study was undertaken at Zonal Agricultural Research Station, V.C. Farm, Mandya which comes under Southern Dry zone of Karnataka during Kharif-2015 and Kharif-2016 to investigate the effect of drip fertigation on nutrient uptake andyield of drip irrigated hybrid maize (Zea mays L.). The experiment was laid out in a Randomized Complete Block Design using factorial concept involving different fertigation intervals and duration with varied levels of fertilizers and replicated thrice. The results revealed that application of 125 percent of recommended nitrogen and potassium through drip fertigation with four or eight days interval with fertigation duration of $25 \%$ at $0-30 \mathrm{DAS}+50 \%$ at $31-50 \mathrm{DAS}+$ $25 \%$ at 51-80 DAS resulted in higher kernel yield $\left(86.85 \mathrm{q} \mathrm{ha}^{-1}\right)$ and stover yield $(103.73 \mathrm{q}$ $\mathrm{ha}^{-1}$ ). Whereas, drip fertigation of $75 \%$ of recommended nitrogen and potassium with the same fertigation duration was found on par with $100 \%$ recommended NPK application under surface irrigation method $\left(69.34,79.80 \mathrm{q} \mathrm{ha}^{-1}\right.$ and $68.81,79,20 \mathrm{q} \mathrm{ha}^{-1}$, respectively). The higher net returns and B: C was found in drip fertigation treatments with the above combinations when compared to control where surface irrigation method was followed.

\section{Introduction}

Fertigation with drip irrigation practice is gaining higher momentum in present day crop production. Because water is the vital source for crop production and is the most limiting factor in Indian agricultural scenario. Though India has the largest irrigation network, the irrigation efficiency does not exceed $40 \%$. Due to water scarcity, the available water resources should be very effectively utilized through water saving irrigation technologies. The need of the hour is, therefore, to maximize the production per unit of water and nutrients as well. Therefore, while giving fertigation, it is very important to consider how much fertilizer to be given and when to give the fertigation and also the crop stage and its nutrient demand, thereby one can achieve higher water and nutrient efficiency in addition to higher yield and economic returns.

Maize is one of the most versatile crops across the world where it was grown throughout the year one or the other place. In India, about 25 per cent of the maize produced is used for human consumption, 49 per cent in poultry and 12 per cent as cattle feed and 12 per cent 
in food processing industries mainly as starch and one per cent each in brewery and seed (Jat et al., 2009). In India, it is cultivated in an area of 9.4 million hectare with a production 22.27 million tonnes. However, the productivity is $2.5 \mathrm{t} \mathrm{ha}^{-1}$ which is much lower than the global average. Karnataka being major maize producing state alone contributes 16.5 per cent of the total maize production with an area of 1.3 million hectare and production of 4.0 million tonnes (Anon., 2016) with a productivity of $2883 \mathrm{~kg} \mathrm{ha}^{-1}$.In present day scenario, maize is replacing many other traditional crops in the state. Being most exhaustive crop maize extracts more nutrients and also responds well to the irrigation as it's one of the crops with higher yield potential. Since water and nutrients are the critical inputs for agriculture their better management and effective utilization is very much essential for successful crop production and is also a serious challenge to future food security and environmental sustainability (Hanumanth et $a l ., 2016)$. So, in this regard drip irrigation and fertigation practices are proven better for efficient nutrient and water management in many commercial crops and also field crops including sugarcane, rice, cotton etc. due to the direct application of water and nutrients in the vicinity of root zone. With this background present study was undertaken to know the effect of different fertigation treatments including different fertigation durations, intervals and fertilizer levels on yield and nutrient uptake of hybrid maize in Southern dry zone of Karnataka.

\section{Materials and Methods}

A Field experiment was conducted during Kharif-2015 and Kharif- 2016 at Zonal Agricultural Research Station, V.C. Farm, Mandya, Southern Dry Zone (Zone-6) of Karnataka. The soil in the experimental site was sandy loam with low organic carbon content. The initial nitrogen, phosphorus and potassium status of the soil were 248.4, 32.50 and $189.3 \mathrm{~kg}$ per ha, respectively. The soil $\mathrm{pH}$ was 6.9 with an EC of $0.32 \mathrm{dSm}^{-1}$. The hybrid maize Nithyashree was used in study. The field experiment was laid out in a Randomized Complete Block Design with three replications using factorial concept involving different fertigation intervals of once in 4 days $\left(\mathrm{I}_{1}\right)$ and 8 days interval $\left(\mathrm{I}_{2}\right)$ with fertigation duration as $\mathrm{D}_{1}: 25 \% \mathrm{RDF}$ (from sowing to 30 DAS) $+50 \%$ RDF (31 to 50 DAS) $+25 \%$ RDF (51 to $80 \mathrm{DAS}$ ) andD $2: 50 \% \mathrm{RDF}$ (from sowing to $30 \mathrm{DAS}$ ) $+25 \% \mathrm{RDF}$ (31 to 50 DAS) $+25 \%$ RDF (51 to 80 DAS)with varied levels of fertilizers i.e. $75 \%\left(\mathrm{~F}_{1}\right), 100 \%\left(\mathrm{~F}_{2}\right)$ and $125 \% \quad\left(\mathrm{~F}_{3}\right)$ of recommended NPK. Phosphorus was applied as basal dose through soil applications. In the control treatment the recommended package of practices with surface irrigation and soil application of $(50 \%$ $\mathrm{N}$ and $100 \%$ PK basally with one top dress at 40 DAS) of fertilizer was followed. The drip line was passed in between paired row. This system included pump, filter units, fertigation tank, ventury, main line and sub line with control valves for each plots to regulate the fertigation frequency and duration. The calculated quantity of phosphorus was applied to all the treatments through single super phosphate by soil application basally, whereas, nitrogen and potassium were supplied through drip fertigation starting from $6^{\text {th }}$ days after sowing as per the treatments using water soluble urea and muriate of potash, respectively. Drip irrigation was given once in two days and fertigation was as per the treatments. The observations of the crop yield and nutrient uptake was recorded and the data was subjected to statistical analysis.

\section{Results and Discussion}

\section{Kernel and stover yield of maize}

The pooled data of kernel and stover yield of maize as influenced by various fertigation 
treatments was discussed in this section (Table 1). The fertigation interval under the study did not influence the yield of maize significantly. However, comparatively higher values were observed with four days fertigation interval compared to eight days interval. Among fertigation durations, significantly higher kernel (80.32 $\left.\mathrm{q} \mathrm{ha}^{-1}\right)$ and stover yield (95.12 q $\mathrm{ha}^{-1}$ ) were recorded in the treatment with fertigation duration given as 25 per cent RDF from sowing to $30 \mathrm{DAS}+50$ per cent from 31 to 50 DAS + 25 per cent from 51 to 80 DAS compared to fertigation duration of 50 per cent RDF from sowing to 30 DAS +25 per cent from 31 to 50 DAS + 25 per cent from 51 to 80 DAS (76.57 and $90.49 \mathrm{q} \mathrm{ha}^{-1}$, respectively). Further, application of 125 per cent RDF recorded higher kernel and stover yield (84.41 and $103.4 \mathrm{q} \mathrm{ha}^{-1}$, respectively) followed by 100 per cent RDF (77.56 and $95.85 \mathrm{q} \mathrm{ha}^{-1}$, respectively) and the lower values were observed with the application of 75 per cent RDF (73.37 and $84.88 \mathrm{q} \mathrm{ha}^{-1}$, respectively).

The interaction between fertigation interval and fertigation duration as well as fertigation interval and fertilizer levels found no significant with respect to the yield of maize. Wherein the interaction of fertigation duration and fertilizer levels had significantly influenced the yield of maize and higher kernel and stover yield were observed with application of 125 per cent RDF fertigated with the duration of 25 per cent RDF from sowing to 30 DAS + 50 per cent from 31 to 50 DAS + 25 per cent from 51 to 80 DAS (86.18 and $103.82 \mathrm{q} \mathrm{ha}^{-1}$, respectively) and lowest parameters were realized with the application of 75 per cent of RDF fertigated as 50 per cent RDF from sowing to 30 DAS +25 per cent from 31 to 50 DAS + 25 per cent from 51 to 80 DAS (69.52 and 78.27 $\mathrm{q} \mathrm{ha}^{-1}$, respectively).

The interaction of fertigation interval, duration and fertilizer levels together influenced the yield of maize and found significantly superior over the control. Among those, higher kernel $\left(86.85 \mathrm{q} \mathrm{ha}^{-1}\right)$ and stover yield (103.73 q ha $\left.{ }^{-1}\right)$ were noticed with the interaction comprised of 125 per cent RDF fertigated once in four days as 25 per cent RDF from sowing to $30 \mathrm{DAS}+$ 50 per cent from 31 to $50 \mathrm{DAS}+25$ per cent from 51 to 80 DAS which was on par with treatment comprised of 125 per cent RDF fertigated once in eight days as 25 per cent RDF from sowing to $30 \mathrm{DAS}+50$ per cent from 31 to 50 DAS + 25 per cent from 51 to 80 DAS $\left(85.52\right.$ and 102.23 q $\mathrm{ha}^{-1}$, respectively).

However, the lowest values were recorded in the control with the surface irrigation soil application of fertilizers (68.81 and 79.2 $\mathrm{q}$ ha 1 , respectively) and found to be on par with application of 75 per cent RDF fertigated once in eight days as 50 per cent RDF from sowing to $30 \mathrm{DAS}+25$ per cent from 31 to $50 \mathrm{DAS}+$ 25 per cent from 51 to 80 DAS (69.34 and $79.80 \mathrm{q} \mathrm{ha}{ }^{-1}$, respectively) which further reflected on harvest index of the crop (Table $1)$.

The kernel and stover yield of maize differed significantly under drip fertigation. Since the economic yield is a part of total biological yield, accumulation of total dry matter with better growth and development of crop helps in enhancement of economical yield of crop. Assessment of maize yield in different treatments indicated that significantly higher kernel and stover yield was observed with drip fertigation with higher dose of nutrient application and nutrient supply coinciding the crop requirement which could be correlated to improved growth parameters (Table 2) such as higher plant height $(\mathrm{r}=0.87)$, number of leaves $(\mathrm{r}=0.77)$ and leaf area $(\mathrm{r}=0.86)$ and yield parameters viz., cob length $(\mathrm{r}=0.84)$, kernel rows $\mathrm{cob}^{-1} \quad(\mathrm{r}=0.83)$, kernel weight $\mathrm{cob}^{-1}$ $(\mathrm{r}=0.95)$ and 100 kernel weight $(\mathrm{r}=0.87)$. Lower kernel and stover yield was observed with surface irrigation. 
Table.2 Correlation and regression equation for growth and yield components with yield as influenced by fertigation interval, duration and fertilizer levels

\begin{tabular}{|c|c|c|c|c|}
\hline \multirow[t]{2}{*}{ Sl. No. } & \multirow[t]{2}{*}{ Parameters } & \multirow{2}{*}{$\begin{array}{l}\text { Correlation co-efificient } \\
(\mathbf{r})\end{array}$} & \multirow{2}{*}{$\begin{array}{l}\text { Regression equation } \\
\text { Y }\left\{\text { Kernel yield }\left(\mathbf{k g ~ h a}^{-1}\right)\right\}\end{array}$} & \multirow[t]{2}{*}{$\mathbf{R}^{2}$} \\
\hline & & & & \\
\hline \multicolumn{5}{|c|}{ Between yield vs growth components } \\
\hline 1. & Plant height at harvest $(\mathrm{cm})$ & $0.87 * *$ & $Y=0.5991 X-30.92$ & 0.7554 \\
\hline 2. & Number of leaves & $0.77 * *$ & $Y=7.1879 X-10.43$ & 0.6002 \\
\hline 3. & Leaf area at harvest $\left(\mathrm{cm}^{2}\right.$ plant $\left.{ }^{-1}\right)$ & $0.86^{* * *}$ & $Y=0.0072 X+29.782$ & 0.7471 \\
\hline 4. & Total dry matter production $\left(\mathrm{g}\right.$ plant $\left.{ }^{-1}\right)$ & $0.87 * *$ & $Y=0.2587 X+1.775$ & 0.7605 \\
\hline \multicolumn{5}{|c|}{ Between yield vs yield components } \\
\hline 1. & Cob length $(\mathrm{cm})$ & $0.84 * *$ & $Y=3.8598 X-8.5238$ & 0.7026 \\
\hline 2. & Kernel rows $\mathrm{cob}^{-1}$ & $0.83 * *$ & $Y=6.4482 X-17.328$ & 0.6828 \\
\hline 3. & Kernel weight $\mathrm{cob}^{-1}(\mathrm{~g})$ & $0.95 * *$ & $Y=0.4494 X+16.824$ & 0.9003 \\
\hline 4. & 100 kernel weight (g) & $0.87 * *$ & $Y=4.5412 X-68.695$ & 0.7556 \\
\hline
\end{tabular}

Note: The independent variable $\mathrm{X}$ refers to the parameters listed in serial number,

$\mathrm{Y}$ is dependent variable kernel yield in $\mathrm{kg} \mathrm{ha}^{-1}$.

**Correlation is significant at $\mathrm{p}=0.01$

Table.3 Economics of maize as influenced by fertigation interval, duration and fertilizer levels

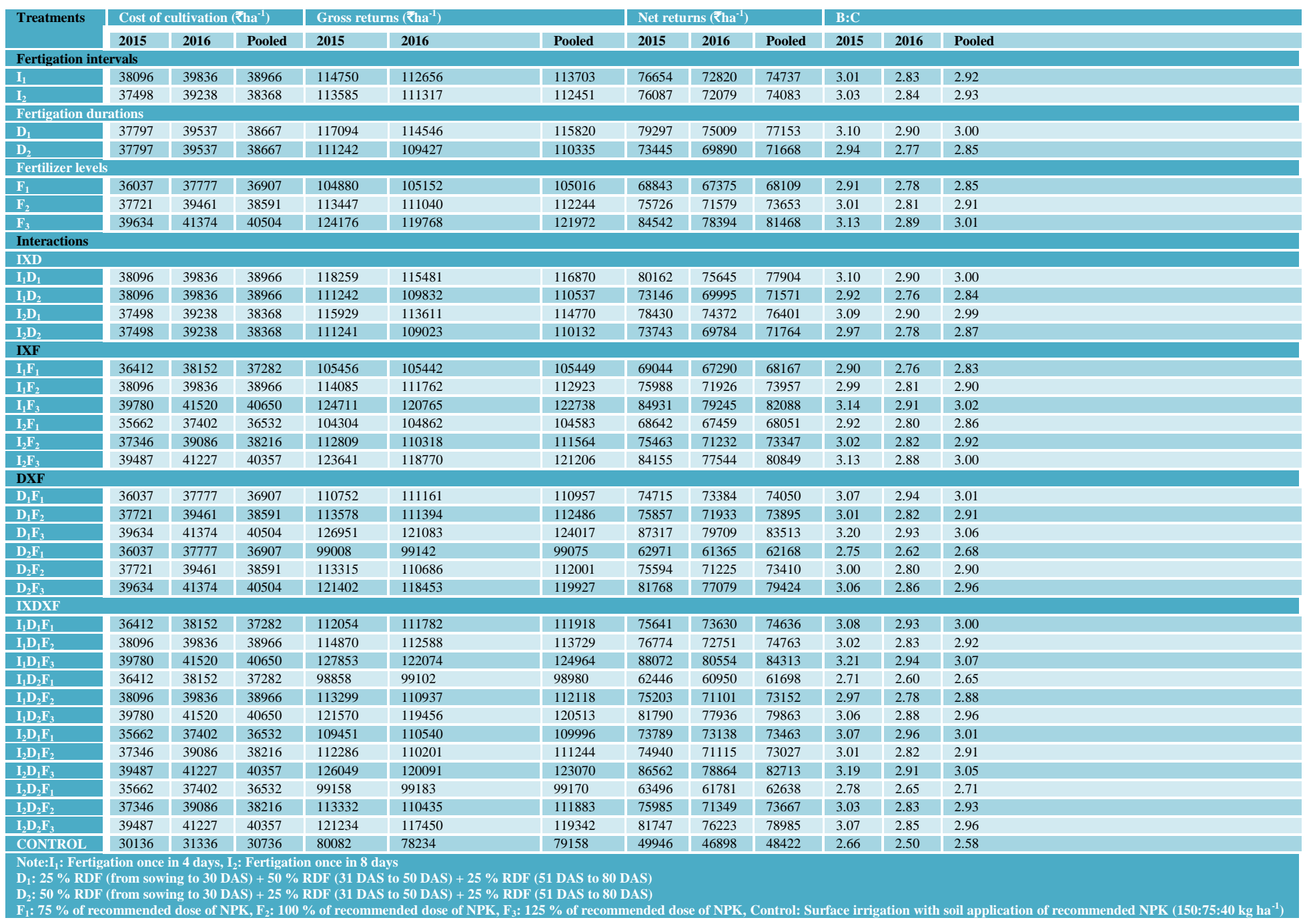


Fig.1 Kernel and stover yield of maize as influenced by fertigation interval, duration and fertilizer levels

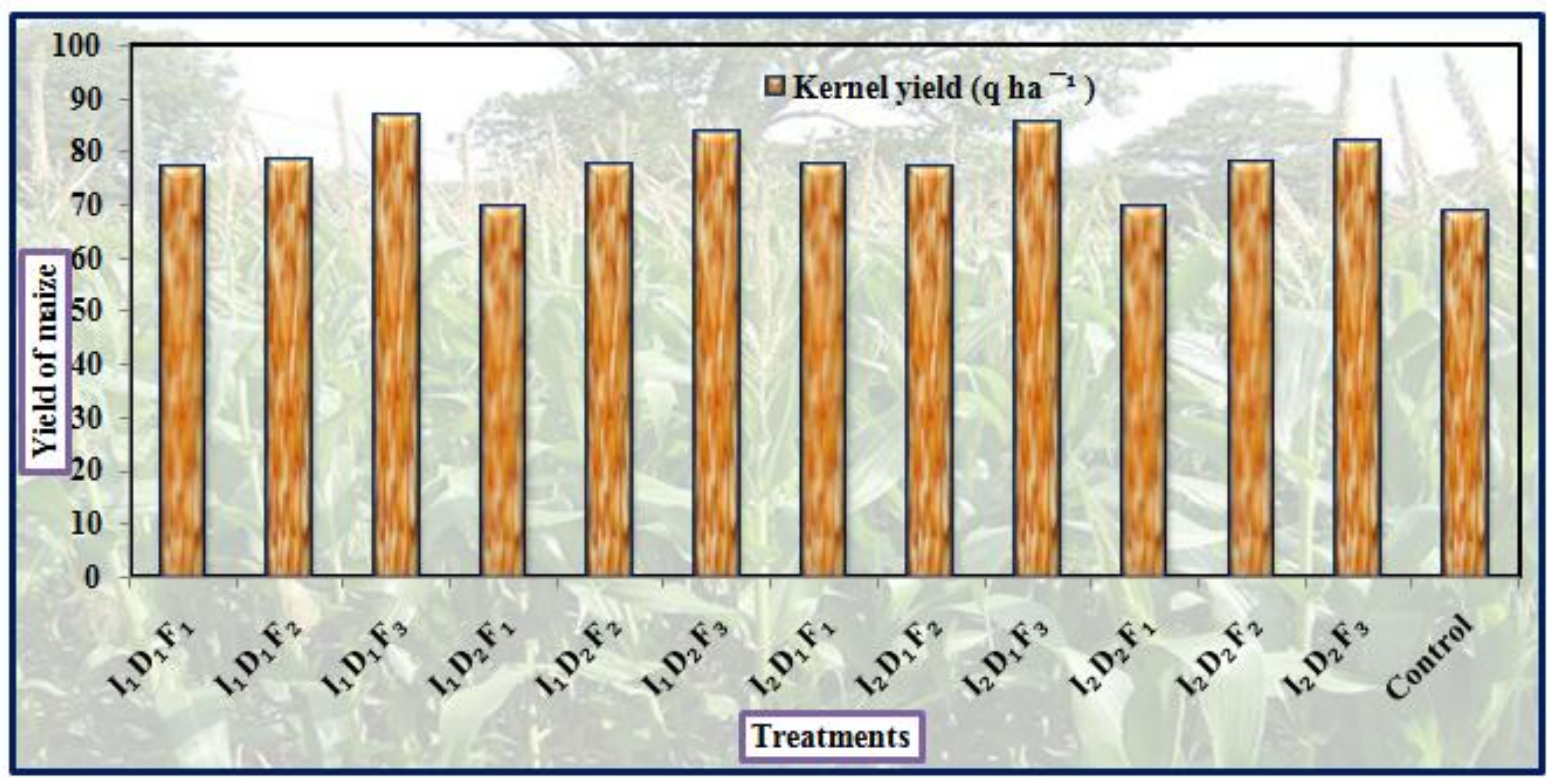

Fig.2 Cost of cultivation, gross returns, net returns and B: C ratio of maize as influenced by fertigation interval, duration and fertilizer levels

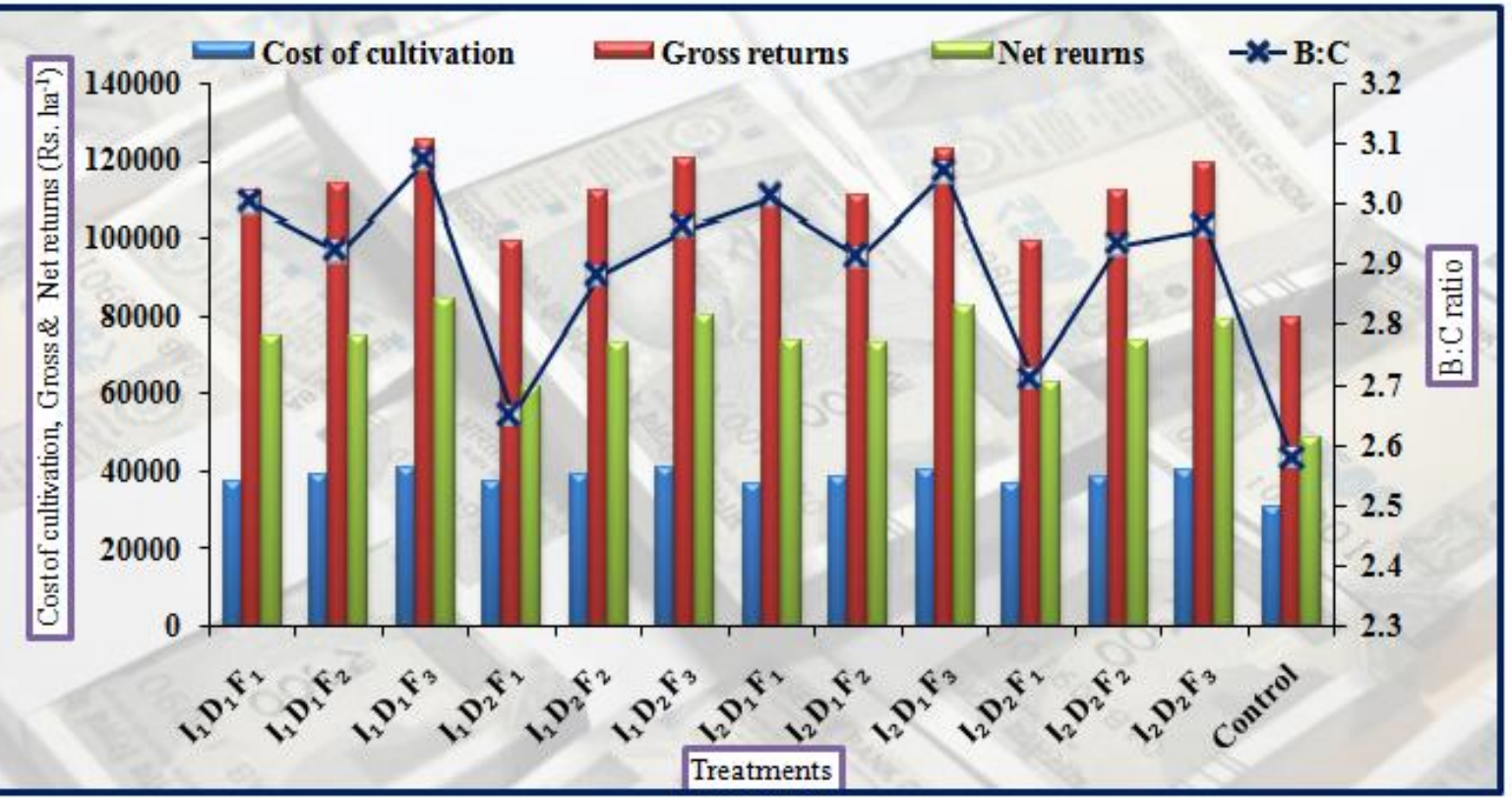

Legend:

Fertigation intervals (I) $\mathbf{I}_{1}$ : Fertigation once in 4 days $\mathbf{I}_{2}$ : Fertigation once in 8 days Fertigation duration (D)

$\mathbf{D}_{1}: 25 \%$ RDF (from sowing to $\left.30 \mathrm{DAS}\right)+50 \% \mathrm{RDF}$ (31 to $\left.50 \mathrm{DAS}\right)+25 \% \mathrm{RDF}$ (51 to $80 \mathrm{DAS}$ )

$\mathbf{D}_{2}: 50 \%$ RDF (from sowing to $\left.30 \mathrm{DAS}\right)+25 \%$ RDF (31 to $\left.50 \mathrm{DAS}\right)+25 \%$ RDF (51 to $80 \mathrm{DAS}$ )

Fertilizer levels (F) $\mathbf{F}_{1}: 75 \% \mathrm{RDF}, \mathbf{F}_{2}: 100 \% \mathrm{RDF}, \mathbf{F}_{3}: 125 \% \mathrm{RDF}$

Control (C): RDF with surface irrigation (150:75:40 $\left.\mathrm{kg} \mathrm{NPK} \mathrm{ha}^{-1}\right)$ 
Frequent split application of fertilizers in drip irrigation coinciding with the actual crop nutrient demand and supplied more nutrients at peak time without any nutrient stress which might have resulted in higher yield of maize. Scheduling fertigation once in four or eight days might not differ but matched with crop demand (Hendawy and Hokam, 2007). In surface irrigation method, initial application of nutrient as basal was more which might allow leaching away of nutrients from the root zone (Ibrahim et al., 2016). These results are in accordance with the studies of Rajput and Patel (2006) wherein yield of onion was not significantly affected in daily, alternate day andweekly fertigation intervals. Moreover, there was increased solubility and availability of nutrients to the root zone in case of fertigation and least or no loss of fertilizers might have taken place as they are supplied in small doses in regular scheduled fertigation (Anusha, 2015). Richa Khanna (2013) documented that 75 per cent recommended fertilizer in drip fertigation recorded on par yield with application of 100 per cent recommended fertilizer through soil application (focused more fertilizer application as basal dose with one top dress) in maize and similar findings were observed by Rekha (2014) in rice.

\section{Economics of maize}

Economics of maize as influenced by fertigation interval, duration and fertilizer levels are depicted in terms of cost of cultivation, gross returns, net returns and B: C as indicated in Table 3.

Individually higher cost of cultivation, gross returns, net returns and $\mathrm{B}$ : $\mathrm{C}$ ratio were realized with the fertigation interval with four days (38966, 113703, $74737 \mathrm{ha}^{-1}$ and 2.92, respectively), fertigation duration with 25 per cent RDF from sowing to $30 \mathrm{DAS}+50$ per cent from 31 to $50 \mathrm{DAS}+25$ per cent from 51 to 80 DAS (38667, 115820, $77153 \mathrm{ha}^{-1}$ and 3.0, respectively) and fertilizer level of 125 per cent RDF (40504, 121972, $80699 \mathrm{ha}^{-1}$ and 3.01 , respectively).

Among interactions, the higher cost of cultivation, gross returns, net returns and B: C ratio were observed with the combination of fertigation interval with four days with fertigation duration as 25 per cent RDF from sowing to 30 DAS +50 per cent from 31 to 50 DAS + 25 per cent from 51 to 80 DAS along with 125 per cent RDF (40650, 124964, $84313 \mathrm{ha}^{-1}$ and 3.07, respectively). On the other hand, lower cost of cultivation, gross returns, net returns and $\mathrm{B}$ : $\mathrm{C}$ ratio was reported with the control (30736, 79158, $48422 \mathrm{ha}^{-1}$ and 2.58 , respectively).

The higher cost of cultivation under drip fertigation was mainly due to initial investment on drip installation but it could be compensated by higher yield of crops resulted in higher net returns. The lower net returns under surface irrigated and soil application under control treatment is mainly due to poor net returns realized by poor crop yield. Present investigation suggest that application of fertilizers through fertigation in four or eight days interval matching the crop demand such that it should be available as per crop demand for realizing higher yield and net returns by harnessing the yield potential of hybrid maize than the traditional method of water and nutrient application where it may undergo more losses than the crop uptake.

\section{Acknowledgement}

I acknowledge the government of Karnataka and Zonal Agricultural Research Station, V. C. Farm, Mandya, University of Agricultural Sciences, Bengaluru for providing financial assistance and other facilities for conducting the research work under RKVY project on "Precision farming technique in maize". 


\section{References}

Anonymous, 2016, Maize special report, www.geofin.co.in

Anusha, S. Nagaraju, Shankaralingappa, B.C. Sheshadri, T. Channabasavegowda, R. Shankar, A. G. and Mallikarjuna, G.B., 2015, Influence of fertigation interval and fertilizer combinations on growth and yield of direct seeded drip irrigated aerobic rice. The Ecoscan, 9 ( 1 \&2): 299-303.

Hanumanth, M. H., Angadi, S. S. and Patil, R. H., 2016, Water and nutrient use efficiencies in agriculture and the role of cereals- A review. J. Farm Sci., 29 (3): 299-306.

Hebbar, S. S., Ramachandrappa, B. K., Nanjappa, H. V. and Prabhakar, M., 2004, Studies on NPK drip fertigation in field grown tomato (Lycopersiocon esculentus Mill.). European J. Agron., 21: 117-127.

Hendawy and Hokam., 2007, Effect of drip irrigation frequency on grain yield, water use efficiency of maize. Season Res., 36 (6): 111-119.

Pushpa, K., Devakumar, N., Murthy, R. K., Nagaraju and Krishnamurthy. 2007.
Nutrient uptake of rice as influenced by methods of irrigation and nitrogen sources. Env.Eco., 25 (4): 748-751.

Raina, J. N., Sharma, T. and Suman, S., 2011, Effect of drip fertigation with different fertilizers on nutrient distribution in soil, leaf nutrient content and yield of apricot (Prunus aremeniaca L.). $J$. Indian Soc. Soil Sci., 59: 268-277.

Rajput, T. P. S. and Patel, N., 2006, Water and nitrate movement in drip irrigated onion under fertigation and irrigation treatments.Agric. Water Mng.79: 293311.

Rekha, B., 2014, Studies on fertilizer management through drip fertigation in aerobic rice. M.Sc. (Agri.) Thesis, Univ. of Agril.Sci., Bengaluru.

Richa Khanna, 2013, Effect of precision nutrient and water management with different sources and levels of fertilizers on maize production. M.Sc. (Agri.) Thesis, Univ. of Agril.Sci., Bengaluru.

Veeraputhiran, R. and Chinnusamy, C., 2005, Production potential, water and nitrogen use efficiency of hybrid cotton as influenced by drip irrigation and nitrogen fertigation. J. Cotton Res. Dev., 19: 61-65.

\section{How to cite this article:}

Shruthi, M.K., T. Sheshadri and Yogananda, S.B. 2018. Performance of Hybrid Maize as Influenced by Fertigation Management Practices. Int.J.Curr.Microbiol.App.Sci. 7(03): 16011608. doi: https://doi.org/10.20546/ijcmas.2018.703.193 